\title{
Combinatorial Gene Therapy for Bone Regeneration: Cooperative Interactions Between Adenovirus Vectors Expressing Bone Morphogenetic Proteins 2, 4, and 7
}

\author{
Ming Zhao, ${ }^{1}$ Zhuoran Zhao, ${ }^{1}$ Jeong-Tae Koh, ${ }^{2}$ Taocong Jin, ${ }^{3}$ and Renny T. Franceschi ${ }^{1,4}{ }^{4}$ \\ ${ }^{1}$ Department of Periodontics, Prevention, and Geriatrics, School of Dentistry and Center for \\ Craniofacial Regeneration, University of Michigan, Ann Arbor, Michigan \\ ${ }^{2}$ Chonnam National University, Kwangju, South Korea \\ ${ }^{3}$ Molecular Biology Core Laboratory, School of Dentistry, University of Michigan, Ann Arbor, Michigan \\ ${ }^{4}$ Department of Biological Chemistry, School of Medicine, University of Michigan, Ann Arbor, Michigan
}

\begin{abstract}
Bone morphogenetic proteins (BMPs) have demonstrated effectiveness as bone regeneration agents whether delivered as recombinant proteins or via gene therapy. Current gene therapy approaches use vectors expressing single BMPs. In contrast, multiple BMPs are coordinately expressed during bone development and fracture healing. Furthermore, BMPs likely exist in vivo as heterodimeric molecules having enhanced biological activity. In the present study, we test the hypothesis that gene therapy-based bone regeneration can be enhanced by expressing combinations of BMPs. For in vitro studies, mesenchymal cell lines were transduced with individual adenoviruses containing BMP2, 4, or 7 cDNA under control of a CMV promoter (AdBMP2, 4, 7) or virus combinations. Significantly, combined transduction with AdBMP2 plus AdBMP7 or AdBMP4 plus AdBMP7 resulted in a synergistic stimulation of osteoblast differentiation. This synergy is best explained by formation of BMP2/7 and 4/7 heterodimers. To test in vivo biological activity, fibroblasts were transduced with specific virus combinations and implanted into C57BL6 mice. Consistent with in vitro results, strong synergy was observed using combined AdBMP2/BMP7 treatment, which induced twofold to threefold more bone than would be predicted based on the activity of individual AdBMPs. These studies show that dramatic enhancement of osteogenesis can be achieved using gene therapy to express specific combinations of interacting regenerative molecules. J. Cell. Biochem. 95: 1-16, 2005. @ 2005 Wiley-Liss, Inc.
\end{abstract}

Key words: BMP; bone regeneration

Bone morphogenetic proteins (BMPs) are multifunctional growth and differentiation factors belonging to the transforming growth factor- $\beta$ (TGF- $\beta$ ) superfamily. They were first identified by their ability to induce cartilage and bone formation in ectopic sites [Wozney et al.,

Grant sponsor: National Institutes of Health; Grant numbers: DE11723, DE12211, DE13386; Grant sponsor: NIH; Grant number: P30-AR46024; Grant sponsor: NIH/ NCI; Grant number: R24 CA83099.

*Correspondence to: Renny T. Franceschi, PhD, Department of Periodontics, Prevention, and Geriatrics, School of Dentistry, University of Michigan, 1011 North University Avenue, Ann Arbor, MI 48109-1078.

E-mail: rennyf@umich.edu

Received 12 January 2005; Accepted 13 January 2005

DOI 10.1002/jcb.20411

(c) 2005 Wiley-Liss, Inc.
1988]. Subsequently, BMPs were shown to play pivotal roles in the development and morphogenesis of several tissues and organs [Hogan, 1996]. Their osteoinductive potency makes them clinically valuable alternatives to bone autografts and allografts. Recombinant BMPs, particularly BMPs 2,4 , and 7 , have been widely evaluated for possible clinical application to spinal fusions, long bone defects, non-union bone fractures, craniomaxillofacial, and periodontal defects and bone/tooth implant augmentation [King et al., 1997; Giannobile et al., 1998; Geesink et al., 1999; Cochran et al., 2000; Kirker-Head, 2000].

Although BMPs have been approved for certain clinical applications, results of human trials have generally been less successful than earlier animal studies [Winn et al., 2000]. Furthermore, BMP-induced osteogenesis, even under ideal conditions, does not approach the 
efficiency of bone formation seen during normal fracture repair. Reasons for this are unclear, but may be related to the low biological activity and short in vivo half-life of purified rBMPs, the inability of rBMP implants to mimic the route or timing of release of a BMP-producing cell in vivo and/or lack of the appropriate combination of regenerative factors to complement the actions of the implanted rBMP [Franceschi et al., 2004].

Recently, several groups including our own used gene therapy as a means of achieving more sustained BMP delivery [Mason et al., 1998; Riew et al., 1998; Bonadio et al., 1999; Lieberman et al., 1999; Franceschi et al., 2000; Baltzer et al., 2000a,b; Krebsbach et al., 2000; Musgrave et al., 2000; Peng et al., 2002; Rutherford et al., 2002]. Both viral and non-viral vectors have been used to direct the expression of individual BMPs at sites targeted for regeneration. Vectors were either directly delivered to in vivo sites (In Vivo Gene Therapy) or used to transduce cells in tissue culture that were subsequently implanted into animals (Ex Vivo Gene Therapy). This approach is able to induce bone formation at both ectopic and orthotopic sites. Demonstrated bone regeneration was also achieved in several preclinical models including long bone and calvarial critical-sized defects as well as spinal fusions [Riew et al., 1998; Lieberman et al., 1999; Krebsbach et al., 2000; Rutherford et al., 2002].

While these early applications of gene therapy to the bone regeneration field show promise, they do not fully exploit the many advantages of this powerful technology, a technology that can be used to express multiple complementary factors at a single regenerative site. The value of this approach is best illustrated by examining how BMPs function in normal development and fracture repair. Although individual BMPs can induce bone formation, there is strong evidence that these factors normally work together to induced bone formation. For example, BMPs 2, 4 , and 7 are expressed in overlapping patterns during limb development [Lyons et al., 1995; Nishimatsu and Thomsen, 1998]. Similarly, overlapping expression of BMPs 2, 3a, 4, 7, and 8 is observed at various times during fracture healing [Cho et al., 2002]. Although most bone induction studies with BMPs used homodimeric molecules, BMP 2/7 and 4/7 heterodimers can be detected when cDNAs encoding these molecules are coexpressed in cell culture. Furthermore, these BMP hetero- dimers are reported to have greater biological activity than their constituent homodimers [Aono et al., 1995; Hazama et al., 1995; Israel et al., 1996]. Lastly, although heterodimeric BMPs have never been isolated from an in vivo source, BMPs 2 and 7 were initially reported to copurify when extracted from bone [Wozney et al., 1988; Sampath et al., 1990]. Taken together, these studies suggest that BMP gene therapy may be more effective if it is used to express combinations of BMPs rather than single homodimeric molecules.

In the present study, we tested this hypothesis by examining cooperative interactions between adenoviruses expressing BMPs 2, 4, and 7 in vitro and in vivo. As will be shown, strong synergies were observed for AdBMP2/7 or 4/7 combinations in stimulating both osteoblast differentiation and in vivo bone formation. Furthermore, these results are best explained by the formation of BMP2/7 and 4/7 heterodimers having enhanced biological activity.

\section{MATERIALS AND METHODS}

\section{Adenovirus Construction}

Recombinant adenoviruses were constructed using Cre/lox recombination [Hardy et al., 1997]. Briefly, mouse BMP2, 4, or 7 cDNA was inserted into pAdlox to produce pAd-loxBMP2, 4 , and 7 plasmids. Each plasmid was cotransfected with $\psi 5$ DNA into CRE8 cells using the calcium phosphate precipitation method. Primary lysates were collected after 5 days and used to reinfect CRE8 cells. A plaque assay method was used to purify virus from this secondary lysate. Each plaque was screened for the presence of BMP2, 4, or 7 insert using gene-specific primers and polymerase chain reaction (PCR) analysis. Positive plaques were amplified in 293 cells, and the virus was purified by $\mathrm{CsCl}$ gradient ultracentrifugation. Purified virus was stored in $20 \%$ glycerol-phosphatebuffered saline (PBS) and titered using an endpoint dilution assay. AdLacZ (contains cDNA encoding bacterial $\beta$-galactosidase) was purchased from the University of Michigan Vector Core Laboratory (Ann Arbor, MI). Ad-Luc (contains cDNA encoding firefly luciferase) was a generous gift from Dr. William Giannobile (University of Michigan School of Dentistry). AdLacZ was routinely used as a negative control vector based on previous studies showing that this vector does not stimulate bone 
formation regardless of whether virus was directly implanted in experimental animals or used to transduce dermal fibroblasts before implantation [Franceschi et al., 2000; Krebsbach et al., 2000].

\section{Cell Cultures}

The following clonal cell lines were used in this study: C3H10T1/2 (murine pluripotent mesenchymal cell line), ST2 (murine bone marrow stromal cell line), $\mathrm{C} 2 \mathrm{C} 12$ (murine myoblastic cell line), and BLK (murine embryonic fibroblastic cell line). Cells were maintained in Dulbecco's modified Eagle's medium (DMEM) containing 10\% FBS, $100 \mathrm{U} / \mathrm{ml}$ of penicillin, and $100 \mu \mathrm{g} / \mathrm{ml}$ streptomycin (GibcoBRL, Gaithersburg, MD). For in vitro adenovirus transduction, cells were plated at a density of 50,000 cells/ $/ \mathrm{cm}^{2}$ (C3H10T1/2, ST2, and C2C12 cells) or 75,000 cells $/ \mathrm{cm}^{2}$ (BLK cells) in DMEM plus $2 \%$ FBS. Cells were transduced with adenovirus at the indicated titer. After $20 \mathrm{~h}$, cells were transferred to fresh medium containing $2 \% \mathrm{FBS}$ and $50 \mu \mathrm{g} / \mathrm{ml}$ ascorbic acid (AA) and fed every other day unless indicated otherwise. Culture plates for experiments with $\mathrm{C} 2 \mathrm{C} 12$ cells were coated with $50 \mu \mathrm{g} / \mathrm{ml}$ rat tail type I collagen in $0.02 \mathrm{~N}$ acetic acid as instructed by the manufacturer (BD Biosciences, Bedford, MA).

\section{Biochemical Analysis}

All samples were harvested in a lysis buffer containing $10 \mathrm{mM}$ Tris-Cl, $\mathrm{pH}$ 7.4, 0.2\% NP40, and $2 \mathrm{mM}$ PMSF, homogenized by sonication (cell cultures) or using a tissue homogenizer (in vivo implants) and centrifuged. The supernatant was used for the measurement of alkaline phosphatase (ALP) activity as previously described using a $p$-nitrophenyl phosphate substrate [Manolagas et al., 1981]. DNA was measured using a picogreen ${ }^{\mathbb{B}}$ dsDNA quantitation kit as instructed by the manufacturer (Molecular Probes, Inc., Eugene, OR).
In vivo implants were assayed for calcium and phosphate as follows. After measurement of ALP activity, samples were extracted into 15\% trichloroacetic acid overnight. Insoluble material was removed by low-speed centrifugation and supernatants were assayed for calcium with a commercially available kit (Sigma Diagnostics, Inc., St. Louis, MO) and for phosphate using the method of Heinonen and Lahti [1981].

BMP2 and 7 proteins secreted into conditioned medium (CM) and in implants were measured using commercially available ELISA kits (R\&D Systems, Inc., Minneapolis, MN).

\section{RNA Analysis}

Osteoblast marker mRNA expression was measured by real-time quantitative-PCR (RTQ-PCR). The following mRNA sequences were measured: Runx2, osteocalcin (OCN), and bone sialoprotein (BSP). At day 3 (for Runx2) and day 6 (for OCN and BSP) after virus transduction, total RNA was extracted using Trizol reagent (Invitrogen, Carlsbad, CA). RNA was further purified by DNase I treatment using an RNAeasy ${ }^{\circledR}$ kit (Qiagen, Valencia, CA) following the manufacturer's instructions. RT reactions were conducted on $2 \mu \mathrm{g}$ total RNA using TaqMan ${ }^{\circledR}$ Reverse Transcription Reagents and an oligo-dT primer (Applied Biosystems, Foster City, CA). Reactions were at $25^{\circ} \mathrm{C}$ for $10 \mathrm{~min}, 48^{\circ} \mathrm{C}$ for $30 \mathrm{~min}$, and $95^{\circ} \mathrm{C}$ for $5 \mathrm{~min}$. RTQ-PCR was performed in triplicate using the ABI PRISM 7700 Sequence Detection System and data were averaged. Optimized primers and probes for specific mouse genes were purchased from Applied Biosystems (Table I). Each PCR reaction $(30 \mu \mathrm{l})$ contained $1 \mu \mathrm{l} \mathrm{cDNA}(\mathrm{RT}$ product), $15 \mu \mathrm{l}$ TaqMan Universal PCR Master Mix, and $1.5 \mu \mathrm{l}$ mixture of primers and TaqMan probe (FAM dye). The PCR condition used was $50^{\circ} \mathrm{C}$ for $2 \mathrm{~min}, 95^{\circ} \mathrm{C}$ for $10 \mathrm{~min}$ followed by 50 cycles of $95^{\circ} \mathrm{C}$ for $15 \mathrm{~s}$ and $60^{\circ} \mathrm{C}$ for $1 \mathrm{~min}$. The house-keeping gene, glyceraldehyde-3-phosphate dehydrogenase $(G A P D H)$ was used as

TABLE I. PCR Primers and Probes

\begin{tabular}{lll}
\hline Genes & TaqMan $^{\circledR}$ probe (FAM-labeled) & Primer sequence/assay ID \\
\hline OCN & AGCGGCCCTGAGTCTGACAAAGCC & F: GACCTCACAGATGCCAAGCCC \\
$R U N X 2^{\mathrm{a}}$ & AAGCTTCTTTTGGGATCCGAGCACC & Mm00501578-m1 \\
$B S P^{\mathrm{a}}$ & GGTTTCCAGTCCAGGGAGGCAGTGA & Mm00492555-m1 \\
GAPDH ${ }^{\mathrm{a}}$ & TGAACGGATTTGGCCGTATTGGGCG & Mm99999915-g1 \\
\hline${ }^{\text {a Assays-on-Demand }}{ }^{\mathrm{TM}}$ gene expression products. &
\end{tabular}


an endogenous control. Relative standard curves were constructed for each target gene using reference RNA (Applied Biosystems). Serial dilutions were made, and were given arbitrary values corresponding to the dilutions.

\section{In Vitro Mineralization Assays}

In parallel with the examination of markers for osteoblast differentiation, the effect of AdBMPs on mineralized nodule formation was determined. $\mathrm{C} 2 \mathrm{C} 12$ cells were plated in 24-well culture plates and transduced as described above. Twenty-four hours after transduction, cells were transferred to mineralizing media (DMEM with $2 \% \mathrm{FBS}, 50 \mu \mathrm{g} / \mathrm{ml} \mathrm{AA}$, and $5 \mathrm{mM} \beta$ glycerophosphate). Medium was changed every other day and the ability of cells to promote mineralized nodule formation was determined using alizarin red-S (AR-S) staining as described previously [Puchtler et al., 1969; Stanford et al., 1995]. Stained cultures were photographed followed by a quantitative eluting procedure using 10\% (w/v) cetylpyridinium chloride (CPC) in $10 \mathrm{mM}$ sodium phosphate, $\mathrm{pH} \mathrm{7.0,} \mathrm{for} 15 \mathrm{~min}$ at room temperature. Aliquots of these AR-S extracts were diluted tenfold in the $10 \% \mathrm{CPC}$ solution, and the AR-S concentration determined by absorbance measurement at $540 \mathrm{~nm}$ on a multiplate reader (Thermo Electron Corp., Woburn, MA) using an AR-S standard curve in the same solution [Stanford et al., 1995].

\section{Immunoprecipitation and Western Blot Analysis}

CM was prepared from BLK cells infected with the indicated AdBMPs. CM was precleaned with $50 \mu \mathrm{l}$ of protein A/G-agarose beads (Santa Cruz Biotechnology) for $2 \mathrm{~h}$ followed by removal of beads by centrifugation. Five-microgram monoclonal antibody against hBMP2 (MAB3552) or hBMP7 (MAB3541) (R\&D Systems, Inc.) was added to $2 \mathrm{ml}$ of $\mathrm{CM}$ and incubated on a shaker overnight at $4^{\circ} \mathrm{C}$. Fifty microliters of protein $\mathrm{A} / \mathrm{G}$-agarose beads, previously washed in PBS, was added and the mixture incubated for $2 \mathrm{~h}$ at $4{ }^{\circ} \mathrm{C}$. The beads were recovered by centrifugation and washed five times with $1 \mathrm{ml}$ of phosphate-buffered saline. Immunoprecipitated proteins were extracted from the beads with $1 \times$ SDS loading buffer with (reducing condition) or without $50 \mathrm{mM}$ DTT (non-reducing condition). CM or immunoprecipitates were analyzed by SDS-polyacrylamide gel electrophoresis using 4-20\% gels (Invitrogen) under both reducing and non-reducing conditions and transferred to nitrocellulose membranes. The membrane was then incubated for $1 \mathrm{~h}$ in TBST containing 5\% non-fat dry milk powder followed by overnight incubation with primary antibodies (mouse antihBMP2 or 7, Alpha Diagnostics International, San Antonio, TX) at $4^{\circ} \mathrm{C}$. Blots were then incubated with secondary antibody for $1 \mathrm{~h}$ (rabbit anti mouse IgG-HRP conjugate antibody) and visualized using an enhanced chemiluminescence (ECL) reagent, according to the manufacturer's recommendation (Amersham Pharmacia Biotech).

\section{Animal Experiments}

All procedures were approved by the University Committee on the Use and Care of Animals and were in compliance with State and Federal laws. BLK cells were infected with AdLacZ, AdBMP2 or 7 alone or in combination at a multiplicity of infection (MOI) of 100 . The total virus titer was held constant at 200 MOI by adding the appropriate amounts of AdLacZ. After $24 \mathrm{~h}$, cells were trypsinized and $2 \times 10^{6}$ cells/implant were suspended in type I collagen hydrogels as previously described [Krebsbach et al., 2000], with six implants per treatment group. Implants were subcutaneously implanted on the backs of 4 - to 5 -week-old C57BL/ 6 mice (Charles River Laboratories, Inc., Wilmington, MA) as described previously [Franceschi et al., 2004]. Surgery was performed under anesthesia achieved using an Ohmeda Isotec 3 isoflurane machine (BOC Health Care, West Yorkshire, UK). Two longitudinal skin incisions of about $0.8-1.0 \mathrm{~cm}$ in length were made on the dorsal surface of each mouse, and four subcutaneous pockets were formed on both sides of the incisions by blunt dissection. A single transplant was placed into each pocket and incisions were closed with surgical staples.

\section{Measurement of the Kinetics of Adenovirus Expression In Vivo}

BLK cells were transduced with AdLuc or AdBMP2 and subcutaneously implanted into C57BL6 mice as described above. After various times, animals were analyzed for luciferase activity using in vivo luminescence measurements or implants were harvested and BMP2 measured by ELISA. For in vivo luminescence assays, animals were injected with the lucifer- 
ase substrate, luciferin (40 $\mathrm{mg}$ luciferin/25 g body weight) and, 12 min later, luminescence was measured using a Xenogen IVIS $^{\mathrm{TM}}$ Imaging System (Xenogen Corp., Alameda, CA) housed in the Michigan Small Animal Imaging Resource (Department of Radiology, University of Michigan School of Medicine).

\section{Histology}

Implants were removed from mice 4 weeks after surgery. Samples were fixed in $10 \%$ neutral buffered formalin for $24 \mathrm{~h}$, embedded in paraffin, sectioned, and stained with hematoxylin and eosin.

\section{Statistical Analysis}

All experiments were repeated a minimum of two times, and qualitatively identical results were obtained. Statistical analyses were performed using one-way Anova analysis and a Tukey multiple comparison procedure to measure statistical differences among groups. Unless indicated otherwise, experimental data are reported as means and SD of triplicate independent samples.

\section{RESULTS}

\section{AdBMP2/7 and 4/7 Combinations Synergistically Stimulate Osteoblast Differentiation in Several Mesenchymal Cell Lines}

During normal development and fracture repair, multiple BMPs may cooperatively interact to stimulate bone formation. To begin evaluating whether such cooperative interactions can be detected with cultured osteogenic precursors, we initially examined the ability of AdBMP2, 4, and 7 to stimulate the early osteoblast marker, ALP, in three clonal murine cell lines (Fig. 1). C3H10T1/2 and C2C12 cells are both mesenchyme-like cell lines derived from embryonic fibroblasts. On exposure to an appropriate stimulus, C3H10T1/2 cells can differentiate along all four mesenchymal lineages (i.e., muscle, cartilage, fat, and bone) [Taylor and Jones, 1979; Katagiri et al., 1990]. C2C12 cells have more premyoblastic properties in that growth arrest induced by serum withdrawal is sufficient to stimulate cell fusion to myotubes [Yaffe and Saxel, 1977]. However, several studies showed that rBMP treatment can suppress myogenic markers and stimulate osteoblast differentiation in these cells [Katagiri et al., 1994; Namiki et al., 1997]. ST2 cells share
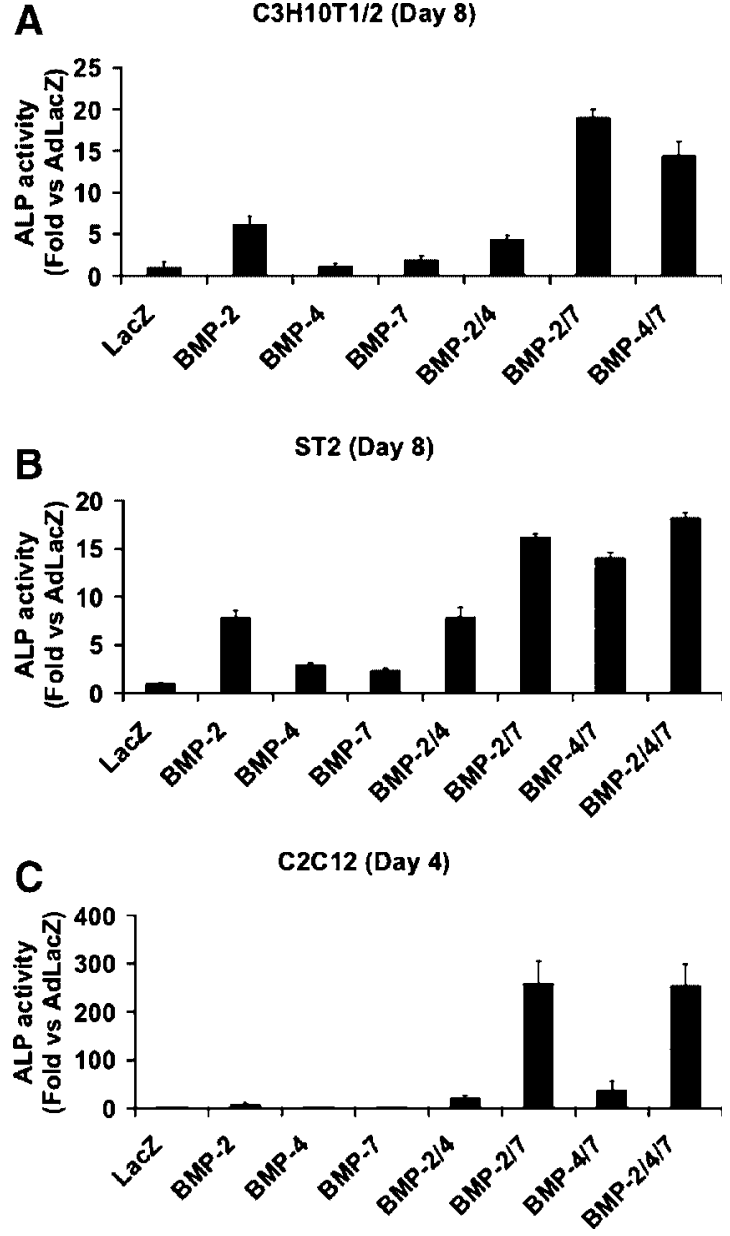

Fig. 1. Synergistic induction of alkaline phosphatase (ALP) activity by transduction of mesenchymal cell lines with AdBMP2, 4 , or 7 combinations. C3H10T1/2 (A), ST2 (B), or C2C12 cells $(\mathbf{C})$ were transduced with the indicated adenovirus at an multiplicity of infection (MOI) of 100 each. Total virus titer was held constant at $300 \mathrm{MOI}$ by addition of the appropriate titer of AdLacZ. Cells were harvested 4 or 8 days after transduction as indicated for the assay of ALP activity. Values are expressed as fold change relative to cells treated with AdLacZ control virus only.

many properties with bone marrow stromal cells and are a good model for this cell type [Otsuka et al., 1999]. When the activity of each adenovirus was examined in the three cell lines, AdBMP2 was found to be most active in stimulating ALP activity relative to AdLacZ treated control cells (fivefold to eightfold stimulation, Fig. 1). Both AdBMP4 and 7 had little or no activity in $\mathrm{C} 2 \mathrm{C} 12$ and $\mathrm{C} 3 \mathrm{H} 10 \mathrm{~T} 1 / 2$ cells and stimulated ALP activity only twofold to threefold in ST2 cells (Fig. 1B). In contrast, combining AdBMP2 or 4 with AdBMP7 synergistically stimulated ALP activity in all three lines (i.e., cells cotransduced with AdBMP2 plus AdBMP7 or AdBMP4 plus AdBMP7 had greater ALP 
activity than would be predicted if effects of individual adenoviruses were additive). The most dramatic synergies were observed in C2C12 cells. In this case, ALP activity in cells treated with AdBMP2 plus AdBMP7 was 30fold greater than the sum of ALP activity in cells individually treated with AdBMP2 or 7 while the activity in cells treated with AdBMP4 plus AdBMP7 was 20-fold greater than the sum of activity in cells individually treated with AdBMP4 and 7 (Fig. 1C). In contrast, ALP activity in cells transduced with AdBMP2 plus AdBMP4 was no greater than that seen in cells transduced with AdBMP2 alone. These results could not be explained by differences in BMP levels between groups in that BMP2 or 7 levels measured by ELISA were similar regardless of whether cells were transduced with AdBMP2 alone, AdBMP7 alone, or AdBMP2 plus AdBMP7 or AdBMP4 plus AdBMP7 (results not shown; however, also see Fig. 5A). Because the strongest synergies between AdBMPs were seen in $\mathrm{C} 2 \mathrm{C} 12$ cells, this cell line was selected for all subsequent in vitro experiments.

A more detailed analysis of the synergistic interactions between AdBMPs is shown in Figure 2 where the response of $\mathrm{C} 2 \mathrm{C} 12$ cells to increasing titers of AdBMP 2, 4, or 7 was examined for individual AdBMPs (panel A) or for AdBMP2 (panel B) or AdBMP4 (panel C) in the presence of AdBMP7 (MOI 300). The magnitude of synergistic interactions between AdBMP2/7 and 4/7 was particularly striking when dose/response relationships were examined. For example, treatment of cells with AdBMP2 or 4 had little or no activity when viruses were individually added at an MOI of 50 , yet this titer of each virus strongly stimulated ALP activity in the presence of AdBMP7. AdBMP7 also synergistically stimulated the response to AdBMP2 and, to a lesser extent, AdBMP4 in the presence of saturating titers of each virus. Furthermore, the optimal titer for each virus was shifted to lower values. Thus, AdBMP2 optimally stimulated ALP activity at an MOI of 200 in the absence of AdBMP7 and at an MOI of 50-100 in the presence of AdBMP7. Similarly, when administered alone, the response to AdBMP4 did not plateau even at an MOI of 300 (the highest titer examined that was not toxic to cells). In contrast, when administered in the presence of AdBMP7, the response to AdBMP4 was saturated at an MOI of
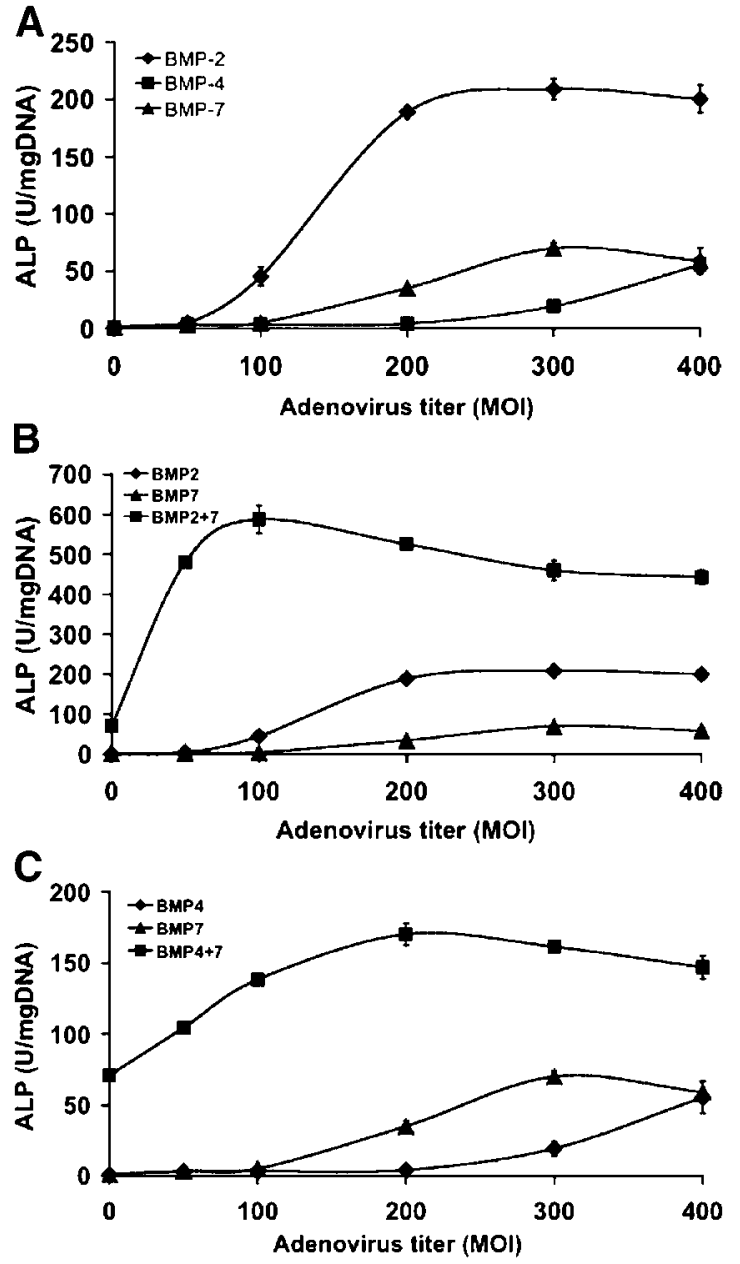

Fig. 2. Dose-dependence of AdBMP $2 / 7$ and 4/7 synergistic activity. $\mathrm{C} 2 \mathrm{C} 12$ cells were transduced with the indicated titers of AdBMP2, 4, or 7 alone (A) or with increasing titers of AdBMP2 or 4 in the presence of $300 \mathrm{MOI}$ AdBMP7 (B, C). Total viral titers were held constant by addition of the appropriate titer of AdLacZ. Cells were harvested 5 days after transduction for ALP assays.

200.This experiment indicates that AdBMP2/7 and 4/7 combinations are synergistic at both suboptimal as well as saturating virus titers.

\section{Stimulation of Mineralization and Gene Expression by AdBMP2/7 and 4/7 Combinations}

To confirm that the AdBMP responses observed for induction of ALP activity were indicative of an overall synergistic stimulation of osteoblast differentiation in $\mathrm{C} 2 \mathrm{C} 12$ cells, we used two additional criteria, mineralization and gene expression, to assess differentiated state. Figure 3 shows the level of mineralization, assessed by Alizarin Red S staining, in C2C12 cells that were treated with the indicated AdBMP combinations and cultured for 8 days in mineralizing medium containing ascorbic 
A

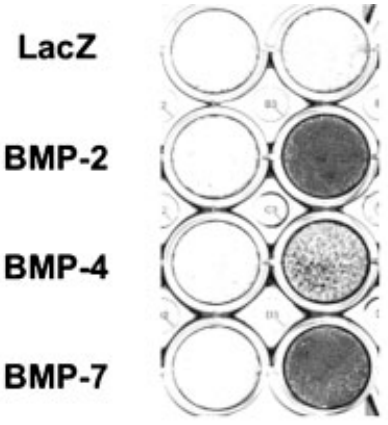

BMP-2/4

BMP-2/7

BMP-4/7

BMP-2/4/7

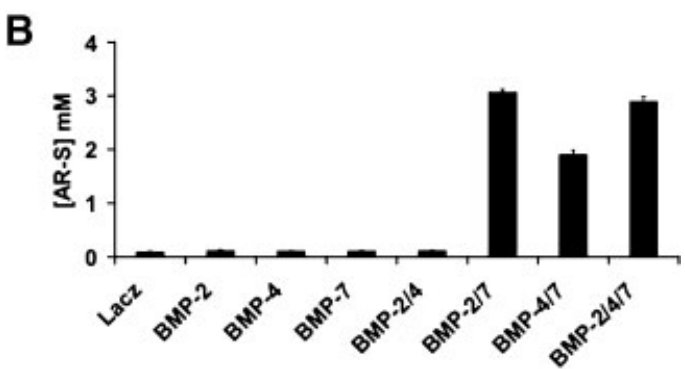

Fig. 3. In vitro mineralization. $\mathrm{C} 2 \mathrm{C} 12$ cells were transduced as in Figure $1 \mathrm{C}$ and assayed for mineralization by staining with Alizarin Red S (AR-S) after culturing for 8 days in mineralizing medium. Photographs of stained culture plates are shown in the upper panels. AR-S was then eluted with $10 \%$ CPC and the dye concentration measured to reflect the mineralization of cells (lower panel).

acid and $\beta$-glycerol phosphate (see Materials and Methods). Little or no mineralization was detected when $\mathrm{C} 2 \mathrm{C} 12$ cells were treated with individual AdBMPs at an MOI of 100. In contrast, AdBMP2/7 or $2 / 4 / 7$ combinations each stimulated mineralization approximately 500fold versus the AdLacZ control while stimulation with AdBMP4/7 was approximately 360fold.

For gene expression studies, mRNA levels for RUNX2, osteocalcin (OCN), and bone sialoprotein (BSP) were assessed using quantitative real-time RT/PCR (Fig. 4). For this experiment, cells were grown for either 3 or 6 days before RNA extraction and analysis. RUNX2 (also known as CBFA1, AML-3, and PEBP $2 \alpha \mathrm{A}$ ) is an essential transcription factor for osteoblast differentiation while OCN and BSP are terminal differentiation markers for mature osteoblasts. RUNX2 mRNA was present at low, but detectable levels in AdLacZ-transduced C2C12 cells. Transduction with AdBMP2 alone increased RUNX2 mRNA 2.1-fold relative to the AdLacZ control. In contrast, AdBMP4 or 7transduced cells had expression levels that were not significantly different from controls. AdBMP2/7 and 2/4/7 combinations stimulated
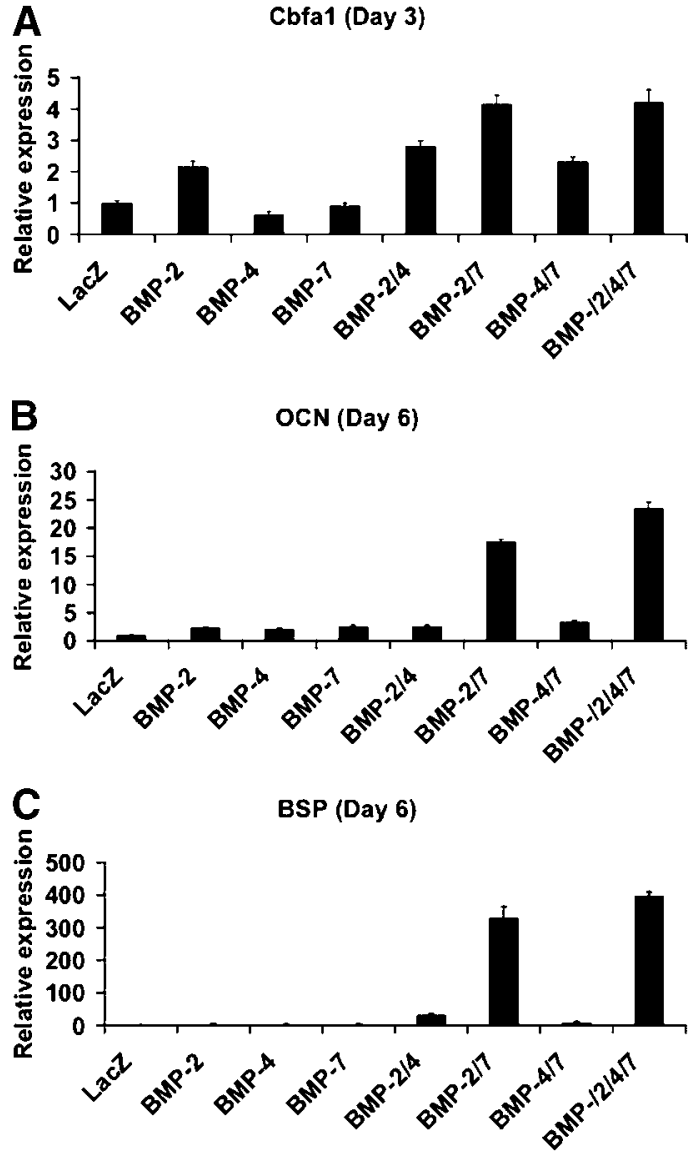

Fig. 4. Induction of osteoblast mRNAs. C2C12 cells were transduced with AdBMP2, 4, or 7 alone or in the combinations indicated. Three or six days after transduction, total RNA was extracted and analyzed for expression of Runx2 (A), OCN (B), and BSP (C) mRNAs with real-time quantitative-RT-PCR as described in Materials and Methods. All mRNA levels in AdBMPtreated cells are expressed relative to levels observed in AdlacZtransduced control cells.

RUNX2 mRNA 4.1-fold, a weakly synergistic response, while levels for AdBMP2/4 or 4/7 were no greater than would be predicted by adding effects of individual AdBMPs. Much larger synergies were observed for the induction of OCN and BSP mRNAs. OCN transcripts were increased 18- and 24-fold, respectively, byAdBMP $2 / 7$ or $2 / 4 / 7$ combinations while only twofold to threefold inductions were obtained with all other AdBMPs. Even more dramatically, BSP transcripts were elevated 329- and 397-fold, respectively, by AdBMP2/7 or $2 / 4 / 7$ combinations. These results together with the ALP induction and mineralization experiments, clearly show that combinations of AdBMP2/7 and, to a lesser extent, AdBMP4/7 stimulate osteoblast differentiation to a greater extent 
than would be predicted from the activity of individual AdBMPs.

\section{Basis for AdBMP2/7 and 4/7 Synergies}

There are at least three possible explanations for the observed synergies between AdBMPs: (i) different BMP homodimers may induce complimentary signals to enhance osteoblast differentiation, (ii) overexpression of specific AdBMP combinations may induce cells to produce other factors capable of enhancing osteoblast differentiation, (iii) certain BMPs interact to form heterodimeric molecules with enhanced biological activity. To discriminate between these possibilities, we compared BMP activity in CM from cells transduced with different individual AdBMPs or AdBMP combinations (see Figs. 5 and 6). As will be shown, our results are best explained by the formation of BMP heterodimers in cells transduced with AdBMP2/7 and 4/7 combinations.
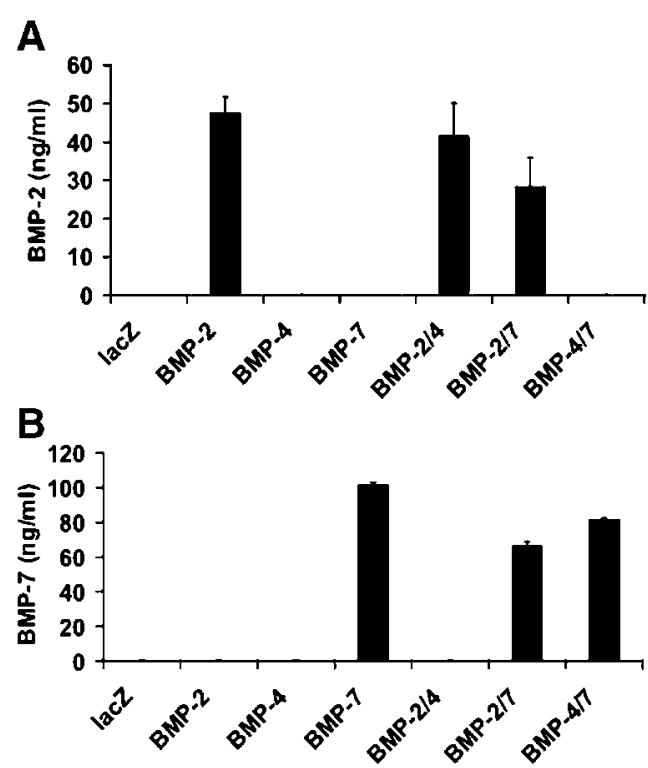

Fig. 5. Biological activity of conditioned medium (CM) from cells transduced with AdBMP combinations. BLK fibroblasts were transduced with the indicated individual AdBMPs (AdBMP2, 4, 7) or AdBMP combinations (BMP2/4, 2/7, 4/7) at an MOI of 100 each. Total viral titer was held constant at $200 \mathrm{MOI}$ by addition of the appropriate titer of AdLacZ. CM was prepared by culturing cells in serum-free medium for $24 \mathrm{~h}$. A, B: BMP concentrations in CM. Levels of BMP2 (A) and BMP7 (B) were measured using specific ELISA kits. C: Biological activity of individual CM and CM combinations. C2C12 cells were plated in 24-well plates and incubated in a total volume of $300 \mu \mathrm{l}$ containing $100 \mu \mathrm{l}$ of each CM or combinations of CM (i.e., BMP2 +4 contains $100 \mu \mathrm{l}$ AdBMP2 CM plus $100 \mu \mathrm{l} \mathrm{AdBMP4}$
For these experiments, CM was prepared from BLK cells, a clonal embryonic fibroblast cell line derived from C57BL6 mice, and then assayed for ability to induce osteoblast differentiation when added to $\mathrm{C} 2 \mathrm{C} 12$ cells. BLK cells differ from $\mathrm{C} 2 \mathrm{C} 12$ cells in that they do not undergo osteoblast differentiation after transduction with AdBMPs. For this reason, their $\mathrm{CM}$ is less likely to produce osteogenic factors that might confuse the interpretation of differentiation assays (result not shown). CM was prepared from BLK cells transduced with AdBMP2, 4, or 7 alone or with AdBMP2/4, 2/7, or $4 / 7$ combinations. As a control to confirm that the expression level of each AdBMP vector did not change when it was transduced into cells in the presence of other AdBMPs, initial experiments measured BMP2 (Fig. 5A) and BMP7 (Fig. 5B) in each CM using highly sensitive ELISAs (BMP4 protein was not assayed because there is no commercially available kit to
D
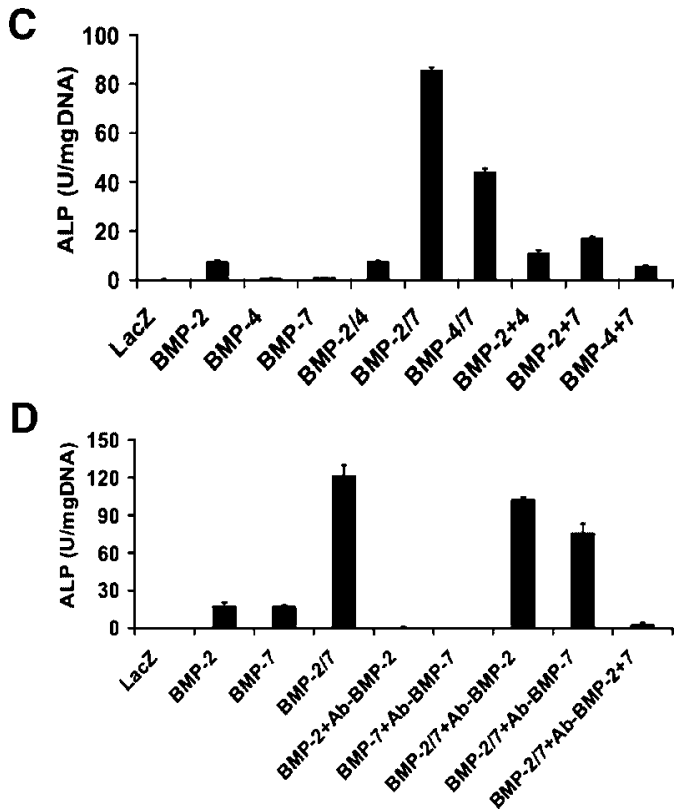

CM; BMP2 +7 contains $100 \mu \mathrm{l}$ AdBMP2 CM plus $100 \mu \mathrm{l}$ AdBMP7 CM; BMP4 + 7 contains $100 \mu \mathrm{l}$ AdBMP4 CM plus $100 \mu \mathrm{l}$ AdBMP7). Volumes were equalized by adding the appropriate volume of CM from AdlacZ-treated cells. After 5 days, cells were harvested for ALP assays. D: Inhibition of CM with BMP blocking antibodies. The same $\mathrm{CM}$ used in panel $\mathrm{C}$ was pretreated with BMP2 or 7 blocking antibodies (Ab-BMP) or normal mouse serum (negative control) for $1 \mathrm{~h}$ at $37^{\circ} \mathrm{C}$. Antibodies were used in concentrations sufficient to completely block the activity of individual BMPs. Following the preincubation period, CM were added to $\mathrm{C} 2 \mathrm{C} 12$ cells cultured in 96-well plates in a total volume of $100 \mu \mathrm{l} /$ well containing $2 \%$ FBS, $50 \mu \mathrm{g} / \mathrm{ml} \mathrm{AA}$. After 5 days, cells were harvested for ALP assays. 


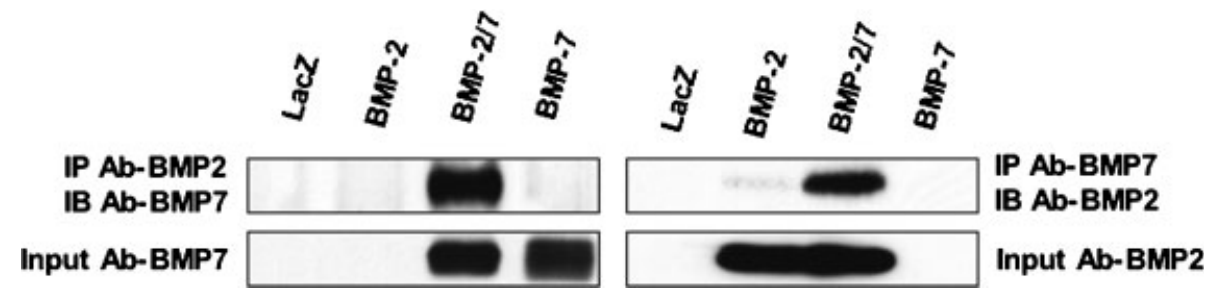

\begin{abstract}
Fig. 6. Identification of $\mathrm{BMP} 2 / 7$ heterodimers. $\mathrm{CM}$ was prepared as described in Figure 5 and immunoprecipitated with BMP2 or 7 antibodies as indicated. Immunoprecipates were analyzed by Western blotting using BMP2 or 7 antibodies. Also shown are Western blots of input CM. SDS-PAGE for detection of BMP2 on Western blots was run under reducing conditions while non-reducing conditions were used for BMP7.
\end{abstract}

measure the murine protein). BMP2 or 7 was only present in CM from cells transduced with the corresponding AdBMP. Furthermore, BMP2 or 7 levels were similar regardless of whether the CM was from cells transduced with a single AdBMP or a combination of two AdBMPs (AdBMP2/7, 2/4, or 4/7).

We next compared the biological activity of different CM using C2C12 cells as an assay system (Fig. 5C). Cells were treated with a constant volume of individual $\mathrm{CM}$ or mixtures of $\mathrm{CM}$ as indicated and assayed for ALP activity after 5 days. Consistent with results shown in Figure 1 where $\mathrm{C} 2 \mathrm{C} 12$ cells were directly treated with AdBMP combinations, CM from cells cotransduced with AdBMP2/7 or 4/7 combinations stimulated ALP activity to a much greater extent that would be predicted from the sum of activities obtained with individual AdBMPs (i.e., CM from cells transduced with AdBMP2/ 7 had tenfold more activity than would be predicted by summing the activities of CM from cells individually transduced with AdBMP2 or 7 while CM from cells transduced with AdBMP4/7 had 28-fold more activity than would be predicted by summing the activities from cells individually transduced with AdBMP4 or 7). Of even greater significance, the enhanced biological activity of CM from cells transduced with AdBMP2/7 or $4 / 7$ combinations could not be reproduced by mixing $\mathrm{CM}$ from cells transduced with individual AdBMP2, 4, or 7 even though equivalent amounts of BMP (by ELISA) were present in the mixed CM (in Fig. 5C, compare BMP2/7 with BMP2 +7 and BMP4/7 with BMP4 + 7).

Lastly, we used neutralizing antibodies against BMP2 or 7 to determine whether the biological activity of each CM could be totally accounted for by BMPs rather than other unknown factors secreted by AdBMP-trans- duced cells. As shown in Figure 5D, antiBMP2 antibody was able to totally block the ALP activity induced by CM from AdBMP2transduced cells while anti-BMP7 antibody totally blocked BMP7 activity. However, the same titer of individual BMP2 or 7 antibodies only reduced the activity of CM from AdBMP2/ 7-transduced cells by 10-40\%; both antibodies were necessary for complete inhibition.

Taken together, these experiments show that when AdBMPs 2/7 or 4/7 combinations are used to transduce BLK cells, a CM with inherently higher biological activity is obtained. This enhanced activity is not seen when equivalent amounts of individual BMP-containing CM are mixed together. We think this result is best explained by the formation of BMP2/7 and 4/7 heterdimers having enhanced biological activity. All BMP dimers, whether homodimeric or heterodimeric, are held together by intermolecular disulfide bonds formed between seven cyteine residues in the $\mathrm{C}$-terminal portion of each constituent peptide [Wozney and Rosen, 1998; Groppe et al., 2002]. Once formed, these disulfides will not readily exchange unless the BMP is exposed to a reducing environment. Because such conditions are not normally found once the BMP is secreted, it is unlikely that individual BMP peptides would exchange between dimers. This lack of exchange may explain why mixing CM from cells transduced with individual BMPs results in much less biological activity than CM from cells transduced with AdBMP2/7 or 4/7 combinations.

More direct evidence for heterodimer formation is provided by the study shown in Figure 6 . For this experiment, CM from BLK cells transduced with AdLacZ, AdBMP2, 7, or the AdBMP2/7 combination were immunoprecipitated with anti-BMP2 antibody and probed on Western blots with anti-BMP7 antibody (left 
four lanes) or were immunoprecipitated with anti-BMP7 antibody and probed with antiBMP2 antibody (right four lanes). The bottom panel shows input CM probed for BMP7 or 2. As is clearly shown, input CM contained similar amounts of BMP7 and 2. However, in samples immunoprecipated with anti-BMP2 antibody, BMP7 was only detected in the AdBMP2/7 CM. Similarly, BMP2 was only detected in antiBMP7 immunoprecipitates from the AdBMP2/7 $\mathrm{CM}$ as would be expected if this $\mathrm{CM}$ contained a BMP2/7 complex.

\section{Enhanced In Vivo Osteogenic Activity of AdBMP2/7 Combinations}

A final series of experiments evaluated whether the synergistic interactions between AdBMP2 and 7 observed in cell culture also occur in vivo. For these studies, C57BL6 mice were subcutaneously implanted with syngeneic BLK fibroblasts previously transduced with different adenovirus combinations and loaded onto gelatin sponges (see Materials and Methods). To estimate the duration of adenovirus expression and BMP secretion under these conditions, BLK cells were initially transduced with AdLuc (encodes firefly luciferase) and AdBMP2. In vivo luminescence and BMP2 levels (by ELISA) were measured after increasing times. Because AdLuc uses the same CMV promoter to drive luciferase expression that is used to drive BMP expression in the AdBMP vectors, it should give a good approximation of the duration of virus gene expression in this system. As shown in Figure 7A,B, luciferase activity was highest after 1-2 days, was still clearly detectable after 4 days and declined to background levels after 1-2 weeks. BMP2 levels were also highest at early times, but unlike luciferase, persisted in implants for up to 9 days before returning to background levels at 2 weeks (panel C). These differences are likely related to the different half lives for luciferase (an intracellular protein that turns over rapidly) and BMP2 which is secreted into the extracellular matrix.

BLK cells were next transduced with AdLacZ, AdBMP2, 7, or 2/7 and implanted into mice. As was shown in Figure 5A,B, these cells produced comparable amounts of BMP2 or 7 regardless of whether they were transduced with a single AdBMP or a combination of two AdBMPs. After 4 weeks, implants were harvested and assayed either for biochemical markers of bone forma-
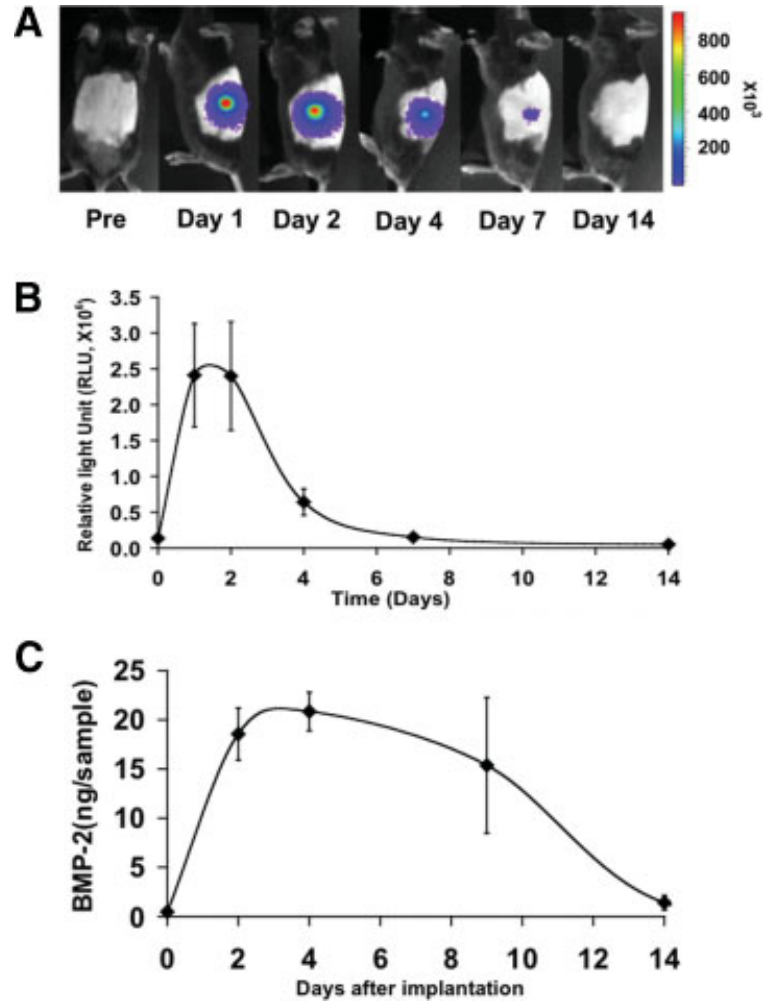

Fig. 7. Time course of adenovirus expression in vivo. BLK cells were transduced with $\operatorname{AdLuc}(\mathbf{A}, \mathbf{B})$ or AdBMP2 (C) at an MOI of 200 and implanted into C57BL6 mice as described in Materials and Methods. After the times indicated, animals (three per group) were injected with luciferin substrate and luminescence was measured in vivo using a Xenogen IVIS $^{\mathrm{TM}}$ imaging system. Separate implants were harvested at the times indicated for assay of total BMP2 by ELISA.

tion (ALP activity, calcium, and phosphate, Fig. 8A-C) or fixed and sectioned for histological analysis (Fig. 8D-G).

AdLacZ implants contained mainly residual carrier and some fibrous tissue, with very low levels of ALP activity, calcium, and phosphate. In contrast, clear evidence of bone formation was apparent in implants containing cells transduced with AdBMP2, 7, or the AdBMP2/7 combination. All ossicles contained residual carrier, areas of cortical and trabecular bone and a clearly defined marrow cavity as well as appreciable amounts of ALP, calcium, and phosphate. However, bone formation in the AdBMP2/7 group was strikingly different from that obtained with the individual AdBMPs. The stimulation of biochemical markers by the AdBMP2/7 combination was greater than would be predicted from the activities of the individual AdBMPs (i.e., was synergistic). Furthermore, ossicles were larger and contained an outer 
A

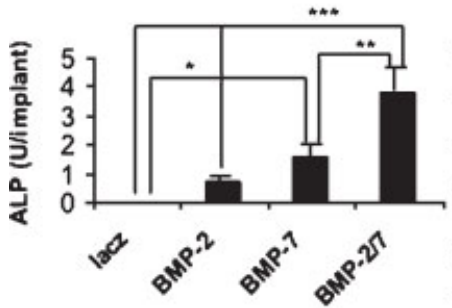

D

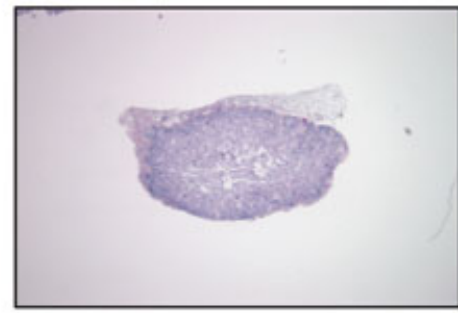

B

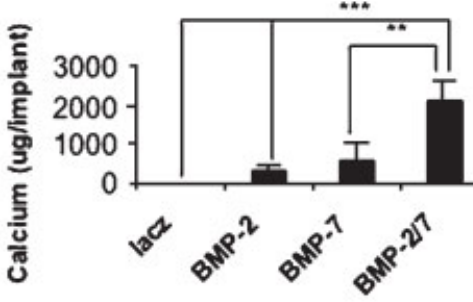

E

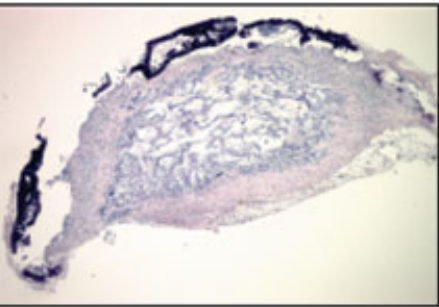

C

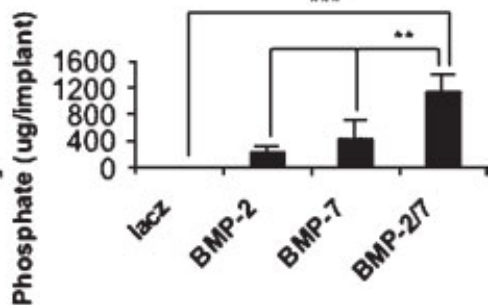

$\mathbf{F}$

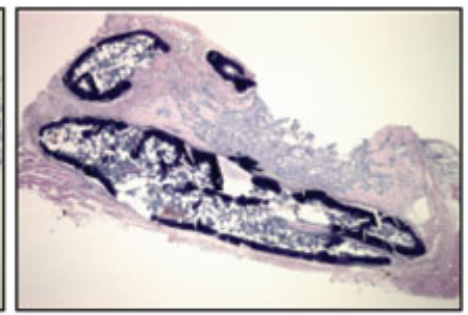

G

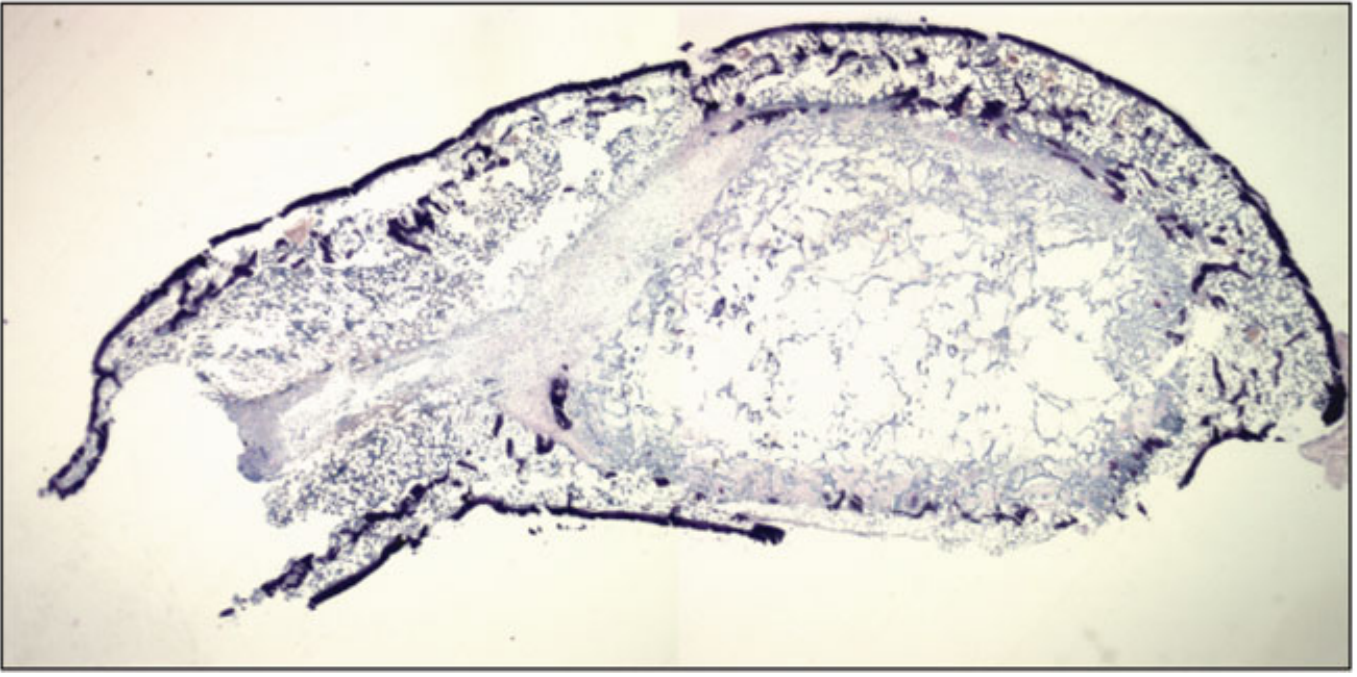

Fig. 8. In vivo osteogenic activity of AdBMP combinations. BLK fibroblasts were transduced with the indicated adenoviruses at an $\mathrm{MOI}$ of 100 each and implanted into $\mathrm{C} 57 \mathrm{BL} / 6$ mice as described in Materials and Methods. After 4 weeks, implants were harvested for determination of (A) ALP activity, (B) calcium, or
(C) phosphate. Significant difference: ${ }^{*}, P<0.05, * *, P<0.01$, ***, $P<0.001$. Histology of the implants is shown in panels $\mathbf{D}-$ G; (D) AdLacZ, (E) AdBMP2, (F) AdBMP7, or (G) AdBMP2/7 (original magnification $\times 4$ for all sections).

\section{DISCUSSION}

dual carrier, trabecular bone, and marrow. In contrast, ossicles formed by AdBMP2 or 7 transduced cells had an incomplete outer bone cortex that formed on one side of the implants (Compare panels E, F with panel G). Furthermore, the implants formed by AdBMP2/7 group were much larger than those of the AdBMP2 or 7 group in terms of implant size and total bone area.
This study explores the premise that the efficacy of gene therapy-based bone induction can be enhanced by expressing unique combinations of BMPs at sites targeted for regeneration. Evidence was presented that AdBMP2/7 and 4/7 combinations have enhanced biological activity in vitro and in vivo that would not be predicted based on the activity of the individual AdBMPs. 
These results are best explained by the formation of BMP2/7 and 4/7 heterodimers in virallytransduced cells that have greatly enhanced biological activity relative to homodimeric BMPs. These studies support our overall hypothesis that enhanced regeneration strategies may be developed by using gene therapy to express unique combinations of complementary or synergistic regenerative molecules.

As was pointed out in the Introduction, the use of gene therapy to express regenerative molecules in vivo has distinct advantages over protein therapy including ability to synthesize factors for prolonged time periods in vivo, thereby overcoming problems related to the short half-life of recombinant proteins, and to express unique combinations of regenerative molecules. Types of combinatorial therapy would include coexpression of factors that stimulate distinct but related pathways necessary for a specific type of tissue regeneration or different components working through a common pathway. Potential advantages of this combinatorial approach include obtaining a more potent biological response with combinations of factors than with single factors and/or gaining the ability to tailor the regeneration response to the particular tissue of interest.

We previously used combinatorial gene therapy to investigate cooperative interactions between BMP2 which signals through cell surface receptors and RUNX2, a transcriptional regulator that is essential for the differentiation of osteoblasts and hypertrophic chondrocytes [Yang et al., 2003]. Our studies showed that combined adenoviral expression of both these factors in mesenchymal cells synergistically stimulated osteogenic differentiation in vitro and bone formation in vivo. This synergy was best explained by AdRunx2 increasing the overall responsiveness of cells to BMPs. Other potential types of combinatorial therapy involving distinct, but complementary signals might include coexpression or sequential expression of growth and differentiation factors that could expand osteoprogenitor populations and induce their differentiation or combinations of factors controlling specific stages of osteogenesis such as chondrogenesis or vascularization.

In the present study, we focus on the use of gene therapy to express unique combinations of BMPs, a family of factors that all use a common signal transduction pathway involving type I and II cell surface receptors. Our choice of which
AdBMPs to study was based on a consideration of the normal process of fracture healing where a clearly defined sequence of growth and differentiation factor expression has been delineated. This sequence includes early expression of specific growth factors such as plateletderived growth factor, fibroblast growth factors, and insulin-like growth factors within the fracture callous and unique temporal patterns of BMP2, 3a, 4, 7, and 8 expression that extend from the initial inflammatory phase to chondrogenic and osteogenic phases [Cho et al., 2002]. These observations taken together with studies indicating that BMP2/7 and 4/7 heterodimers are found in vivo and may have enhanced biological activity prompted us investigate the osteogenic response when cells are transduced with AdBMP2/7 and 4/7 combinations.

Our initial experiments examined the biological activity of individual AdBMPs and combinations in vitro. In all three mesenchymal cell lines examined, transduction with individual AdBMPs resulted in only a modest induction of osteoblast markers with AdBMP2 having higher activity than AdBMP4 or 7. These differences could not be explained by differences in BMP synthesis; in fact, there was actually somewhat less BMP2 than BMP7 in the CM after cell transduction with the same titer of AdBMP2 or 7 (Fig. 5). Consistent with these studies, Cheng et al. recently reported that AdBMP2 has stronger ALP-inducing activity than AdBMP4 and 7 in C3H10T1/2 and C2C12 cells [Cheng et al., 2003].

More dramatic results were obtained when AdBMP combinations were examined. Regardless of the experimental system used (mesenchymal cell lines in vitro or in vivo implantation of virally-transduced cells), we consistently found that transduction with AdBMP2/7 or 4/7 combinations resulted in more osteoblast differentiation/bone formation than would be predicted based on the biological activity of individual AdBMPs. The most dramatic in vitro results were obtained with $\mathrm{C} 2 \mathrm{C} 12$ cells that are known to be highly responsive to BMPs [Katagiri et al., 1994]. Synergistic interactions were particularly dramatic at low viral titers although they persisted even in the presence of saturating virus (Fig. 2). The magnitude of the in vitro response varied with the particular osteoblast marker examined with the most dramatic results being obtained when induction of osteoblast-related mRNAs and mineralization was 
measured. In the case of mRNA induction, dramatic synergies were obtained for both OCN and BSP mRNAs. Both these messages are normally associated with terminally differentiated, mineralizing osteoblasts. Consistent with this result is the strong mineralization response seen in $\mathrm{C} 2 \mathrm{C} 12$ cells treated with AdBMP2/7 or $4 / 7$ combinations. Induction of RUNX2 mRNA that was present at low levels in control $\mathrm{C} 2 \mathrm{C} 12$ cells was less dramatic. Although RUNX2 has been reported to be a BMPresponsive gene in certain systems [Ducy et al., 1997], BMP induction of osteoblast marker mRNAs does not require upregulation of RUNX2 as long as cells already contain some basal level of this factor. For example, BMP strongly induces OCN and BSP mRNAs in MC3T3-E1 preosteoblast cells (which already contain RUNX2), without changing RUNX2 levels [Xiao et al., 2002].

The enhanced biological activity of AdBMP2/ 7 and 4/7 combinations could not be explained by differences in BMP levels between experimental groups or by the induction of accessory factors by different AdBMP combinations. Instead, our results are best explained by the formation of BMP2/7 and 4/7 heterodimers having enhanced biological activity. This concept is supported by studies with conditioned media from virally transduced cells (Fig. 5) and by immunoprecipation data that provided direct evidence for the presence of a BMP2/7 complex (Fig. 6). However, because we have not yet determined the stoichiometry of BMP2/7 or $4 / 7$ complexes, it cannot be firmly concluded that these complexes are exclusively heterodimeric.

In a related study, Zhu et al. [2004] recently reported that CM from A549 epithelial cells transduced with AdBMP2 plus AdBMP7 contained immunoprecipitable complexes containing BMP2 and 7. This CM was more active in stimulating OCN and ALP levels in $\mathrm{C} 2 \mathrm{C} 12$ cells than CM from cells individually transduced with AdBMP2 or 7 or equivalent amounts of purified recombinant BMP2 or 7. In addition, direct gene transfer of AdBMP2 plus AdBMP7 stimulated spinal fusion in a rat model under conditions where AdBMP2 or 7 were totally inactive. Although this study did not directly examine effects of AdBMP2/7 transduction on osteoblast differentiation, results are consistent with the present communication and suggest that BMP2/7 heterodimers have enhanced biological activity in vitro and in vivo. Effects of AdBMP4/7 transduction were not examined.

A final issue raised by our studies has to do with the mechanism of action of heterodimeric BMPs. Interestingly, enhanced activity was only seen when AdBMP7 was combined with AdBMP2 or 4 . In contrast, activity of the AdBMP2/4 combination was no greater than the sum of activities of cells individually transduced with AdBMP2 or 4 (see Figs. 1 and 3-5). Synergistic interactions between AdBMP2/7 or 4/7 combinations were seen at low as well as saturating viral titers (Fig. 2). This finding suggests that heterodimers containing BMP7 may work through a distinct signaling pathway, which differs from, but acts together with BMP2 and 4. These findings are consistent with previous reports indicating that recombinant BMP2 only activates a subfraction of the genes activated by demineralized bone matrix, which contains a heterogeneous mixture of BMPs including BMP7 [Zhou et al., 2004]. BMPs signal through type I and type II receptor kinases. Both receptors are needed to initiate downstream signaling events. Activated receptor phosphorylates R-Smads 1, 5, and 8, which form heterodimeric complexes with Smad 4 to regulate target gene transcription [Hogan, 1996; Nohe et al., 2004]. BMP receptors also stimulate other signaling pathways resulting in activation of p38 mitogen-activated protein kinase (MAPK), extracellular signal-regulated kinases/p42/p44 (ERK1/2) and c-Jun N-terminal kinase (JNK) [Nohe et al., 2004]. While BMP2 and 4 mainly bind to the type I receptors, activin receptor-like kinase 3 (ALK-3 or BMPR1A) and ALK-6 (BMPR1B), BMP7 preferentially binds to ALK-2 [ten Dijke et al., 1994; Nishitoh et al., 1996]. Structurally, the mature regions of BMP2 and 4 share more than 90\% homology at the amino acid level, but their homology with BMP7 is only slightly greater than $50 \%$. Thus, BMPs $2 / 4$ and 7 belong to different subtypes and exhibit different receptor binding properties. When ALK-2 and ALK-3 adenoviruses were co-transduced into $\mathrm{C} 2 \mathrm{C} 12$ cells, ALP induction was much greater than that seen with either receptor alone, indicating that ALK-2 and ALK-3 synergistically induce osteoblast differentiation [Aoki et al., 2001]. This may explain the synergy induced by BMP2/ 7 or 4/7 heterodimers. Alternatively, BMP2 (or 4 ) and 7 may preferentially use different signal transduction pathways (i.e., Smad vs. p38, 
ERK, or JNK MAPK pathways). For example, in the unactivated state, type I and II BMP receptors exist in both preformed type I/II heterodimeric complexes and as separate type I and II complexes. Recent studies by Nohe et al. [2002] showed that Smad activation is mediated by binding of BMPs to preformed type I/II heterodimeric complexes while p38 MAPK activation involves de novo BMP-induced type I/II receptor complex formation. While individual BMP homodimers can activate both these pathways, heterodimers containing BMP7 may have unique actions because, unlike BMP2 and 4, BMP7 binds to activin type II receptors as well as to ALK-2 [Yamashita et al., 1995]. This may give heterodimers the ability to preferentially stimulate non-Smad pathways such as p38, ERK1/2, and JNK MAPK. Further studies will be required to discriminate between these possibilities.

In summary, our results clearly demonstrate that the osteogenic activity of AdBMPs can be dramatically increased by co-tranduction of cells with AdBMP2/7 and 4/7 combinations. Because of their increased biological activity, such vector formulations can achieve bone regeneration at much lower viral titers, thereby minimizing possible toxicity and/or immune responses. Elucidation of the molecular mechanisms underlying this phenomenon, optimization of BMP vector formulations as well as strategies to maximize the production of BMP heterodimers will be important areas for future research.

\section{ACKNOWLEDGMENTS}

This work was supported by National Institutes of Health Grants DE11723, DE12211, and DE13386 (to RTF) and the University of Michigan Core Center for Musculoskeletal Disorders (supported by NIH P30-AR46024). The imaging studies were supported in part by a grant awarded to Dr. Brian Ross at the Center of Molecular Imaging at the University of Michigan (NIH/NCI Grant R24 CA83099).

\section{REFERENCES}

Aoki H, Fujii M, Imamura T, Yagi K, Takehara K, Kato M, Miyazono K. 2001. Synergistic effects of different bone morphogenetic protein type I receptors on alkaline phosphatase induction. J Cell Sci 114:1483-1489.

Aono A, Hazama M, Notoya K, Taketomi S, Yamasaki H, Tsukuda R, Sasaki S, Fujisawa Y. 1995. Potent ectopic bone-inducing activity of bone morphogenetic protein-4/7 heterodimer. Biochem Biophys Res Commun 210:670677.

Baltzer AW, Lattermann C, Whalen JD, Ghivizzani S, Wooley P, Krauspe R, Robbins PD, Evans CH. 2000a. Potential role of direct adenoviral gene transfer in enhancing fracture repair. Clin Orthop 379:S120-S125.

Baltzer AW, Lattermann C, Whalen JD, Wooley P, Weiss K, Grimm M, Ghivizzani SC, Robbins PD, Evans CH. 2000b. Genetic enhancement of fracture repair: Healing of an experimental segmental defect by adenoviral transfer of the BMP-2 gene. Gene Ther 7:734-739.

Bonadio J, Smiley E, Patil P, Goldstein S. 1999. Localized, direct plasmid gene delivery in vivo: Prolonged therapy results in reproducible tissue regeneration [see comments]. Nat Med 5:753-759.

Cheng H, Jiang W, Phillips FM, Haydon RC, Peng Y, Zhou L, Luu HH, An N, Breyer B, Vanichakarn P, Szatkowski JP, Park JY, He TC. 2003. Osteogenic activity of the fourteen types of human bone morphogenetic proteins (BMPs). J Bone Joint Surg Am 85A:1544-1552.

Cho TJ, Gerstenfeld LC, Einhorn TA. 2002. Differential temporal expression of members of the transforming growth factor beta superfamily during murine fracture healing. J Bone Miner Res 17:513-520.

Cochran DL, Jones AA, Lilly LC, Fiorellini JP, Howell H. 2000. Evaluation of recombinant human bone morphogenetic protein-2 in oral applications including the use of endosseous implants: 3-year results of a pilot study in humans. J Periodontol 71:1241-1257.

Ducy P, Zhang R, Geoffroy V, Ridall AL, Karsenty G. 1997. Osf2/Cbfa1: A transcriptional activator of osteoblast differentiation [see comments]. Cell 89:747-754.

Franceschi RT, Wang D, Krebsbach PH, Rutherford RB. 2000. Gene therapy for bone formation: In vitro and in vivo osteogenic activity of an adenovirus expressing BMP7. J Cell Biochem 78:476-486.

Franceschi RT, Yang S, Rutherford RB, Krebsbach PH, Zhao M, Wang D. 2004. Gene therapy approaches for bone regeneration. Cells Tissues Organs 176:95-108.

Geesink RG, Hoefnagels NH, Bulstra SK. 1999. Osteogenic activity of OP-1 bone morphogenetic protein (BMP-7) in a human fibular defect. J Bone Joint Surg Br 81:710718 .

Giannobile WV, Ryan S, Shih MS, Su DL, Kaplan PL, Chan TC. 1998. Recombinant human osteogenic protein1 (OP-1) stimulates periodontal wound healing in class III furcation defects. J Periodontol 69:129-137.

Groppe J, Greenwald J, Wiater E, Rodriguez-Leon J, Economides AN, Kwiatkowski W, Affolter M, Vale WW, Belmonte JC, Choe S. 2002. Structural basis of BMP signalling inhibition by the cystine knot protein Noggin. Nature 420:636-642.

Hardy S, Kitamura M, Harris-Stansil T, Dai Y, Phipps ML. 1997. Construction of adenovirus vectors through Cre-lox recombination. J Virol 71:1842-1849.

Hazama M, Aono A, Ueno N, Fujisawa Y. 1995. Efficient expression of a heterodimer of bone morphogenetic protein subunits using a baculovirus expression system. Biochem Biophys Res Commun 209:859-866.

Heinonen JK, Lahti RJ. 1981. A new and convenient colorimetric determination of inorganic orthophosphate and its application to the assay of inorganic pyrophosphatase. Anal Biochem 113:313-317. 
Hogan BL. 1996. Bone morphogenetic proteins: Multifunctional regulators of vertebrate development. Genes Dev 10:1580-1594.

Israel DI, Nove J, Kerns KM, Kaufman RJ, Rosen V, Cox KA, Wozney JM. 1996. Heterodimeric bone morphogenetic proteins show enhanced activity in vitro and in vivo. Growth Factors 13:291-300.

Katagiri T, Yamaguchi A, Ikeda T, Yoshiki S, Wozney JM, Rosen V, Wang EA, Tanaka H, Omura S, Suda T. 1990. The non-osteogenic mouse pluripotent cell line, C3H10T1/2, is induced to differentiate into osteoblastic cells by recombinant human bone morphogenetic protein-2. Biochem Biophys Res Commun 172:295-299.

Katagiri T, Yamaguchi A, Komaki M, Abe E, Takahashi N, Ikeda T, Rosen V, Wozney JM, Fujisawa-Sehara A, Suda T. 1994. Bone morphogenetic protein-2 converts the differentiation pathway of $\mathrm{C} 2 \mathrm{C} 12$ myoblasts into the osteoblast lineage. [Published erratum appears in J Cell Biol 1995 Feb;128(4):following 713]. J Cell Biol 127: $1755-1766$.

King GN, King N, Cruchley AT, Wozney JM, Hughes FJ. 1997. Recombinant human bone morphogenetic protein-2 promotes wound healing in rat periodontal fenestration defects. J Dent Res 76:1460-1470.

Kirker-Head CA. 2000. Potential applications and delivery strategies for bone morphogenetic proteins. Adv Drug Deliv Rev 43:65-92.

Krebsbach PH, Gu K, Franceschi RT, Rutherford RB. 2000. Gene therapy-directed osteogenesis: BMP-7-transduced human fibroblasts form bone in vivo [In Process Citation]. Hum Gene Ther 11:1201-1210.

Lieberman JR, Daluiski A, Stevenson S, Wu L, McAllister P, Lee YP, Kabo JM, Finerman GA, Berk AJ, Witte ON. 1999. The effect of regional gene therapy with bone morphogenetic protein-2-producing bone-marrow cells on the repair of segmental femoral defects in rats. J Bone Joint Surg Am 81:905-917.

Lyons KM, Hogan BL, Robertson EJ. 1995. Colocalization of BMP 7 and BMP 2 RNAs suggests that these factors cooperatively mediate tissue interactions during murine development. Mech Dev 50:71-83.

Manolagas SC, Burton DW, Deftos LJ. 1981. 1,25-Dihydroxyvitamin D stimulates the alkaline phosphatase activity of osteoblast-like cells. J Biol Chem 256:71157117.

Mason JM, Grande DA, Barcia M, Grant R, Pergolizzi RG, Breitbart AS. 1998. Expression of human bone morphogenic protein 7 in primary rabbit periosteal cells: Potential utility in gene therapy for osteochondral repair. Gene Ther 5:1098-1104.

Musgrave DS, Bosch P, Lee JY, Pelinkovic D, Ghivizzani SC, Whalen J, Niyibizi C, Huard J. 2000. Ex vivo gene therapy to produce bone using different cell types. Clin Orthop 378:290-305.

Namiki M, Akiyama S, Katagiri T, Suzuki A, Ueno N, Yamaji N, Rosen V, Wozney JM, Suda T. 1997. A kinase domain-truncated type I receptor blocks bone morphogenetic protein-2-induced signal transduction in $\mathrm{C} 2 \mathrm{C} 12$ myoblasts. J Biol Chem 272:22046-22052.

Nishimatsu S, Thomsen GH. 1998. Ventral mesoderm induction and patterning by bone morphogenetic protein heterodimers in Xenopus embryos. Mech Dev 74:75-88.

Nishitoh H, Ichijo H, Kimura M, Matsumoto T, Makishima F, Yamaguchi A, Yamashita H, Enomoto S, Miyazono K.
1996. Identification of type I and type II serine/threonine kinase receptors for growth/differentiation factor-5. J Biol Chem 271:21345-21352.

Nohe A, Hassel S, Ehrlich M, Neubauer F, Sebald W, Henis YI, Knaus P. 2002. The mode of bone morphogenetic protein (BMP) receptor oligomerization determines different BMP-2 signaling pathways. J Biol Chem 277: 5330-5338.

Nohe A, Keating E, Knaus P, Petersen NO. 2004. Signal transduction of bone morphogenetic protein receptors. Cell Signal 16:291-299.

Otsuka E, Yamaguchi A, Hirose S, Hagiwara H. 1999. Characterization of osteoblastic differentiation of stromal cell line ST2 that is induced by ascorbic acid. Am J Physiol 277:C132-C138.

Peng H, Wright V, Usas A, Gearhart B, Shen HC, Cummins J, Huard J. 2002. Synergistic enhancement of bone formation and healing by stem cell-expressed VEGF and bone morphogenetic protein-4. J Clin Invest 110: 751-759.

Puchtler H, Meloan SN, Terry MS. 1969. On the history and mechanism of alizarin and alizarin red $\mathrm{S}$ stains for calcium. J Histochem Cytochem 17:110-124.

Riew KD, Wright NM, Cheng S, Avioli LV, Lou J. 1998. Induction of bone formation using a recombinant adenoviral vector carrying the human $B M P-2$ gene in a rabbit spinal fusion model. Calcif Tissue Int 63:357-360.

Rutherford RB, Moalli M, Franceschi RT, Wang D, Gu K, Krebsbach PH. 2002. Bone morphogenetic protein-transduced human fibroblasts convert to osteoblasts and form bone in vivo. Tissue Eng 8:441-452.

Sampath TK, Coughlin JE, Whetstone RM, Banach D, Corbett C, Ridge RJ, Ozkaynak E, Oppermann H, Rueger DC. 1990. Bovine osteogenic protein is composed of dimers of OP-1 and BMP-2A, two members of the transforming growth factor-beta superfamily. J Biol Chem 265:13198-13205.

Stanford CM, Jacobson PA, Eanes ED, Lembke LA, Midura RJ. 1995. Rapidly forming apatitic mineral in an osteoblastic cell line (UMR 106-01 BSP). J Biol Chem 270: 9420-9428.

Taylor SM, Jones PA. 1979. Multiple new phenotypes induced in 10T1/2 and 3T3 cells treated with 5-azacytidine. Cell 17:771-779.

ten Dijke P, Yamashita H, Sampath TK, Reddi AH, Estevez M, Riddle DL, Ichijo H, Heldin CH, Miyazono K. 1994. Identification of type I receptors for osteogenic protein-1 and bone morphogenetic protein-4. J Biol Chem 269: $16985-16988$

Winn SR, Hu Y, Sfeir C, Hollinger JO. 2000. Gene therapy approaches for modulating bone regeneration. Adv Drug Deliv Rev 42:121-138.

Wozney JM, Rosen V. 1998. Bone morphogenetic protein and bone morphogenetic protein gene family in bone formation and repair. Clin Orthop 346:26-37.

Wozney JM, Rosen V, Celeste AJ, Mitsock LM, Whitters MJ, Kriz RW, Hewick RM, Wang EA. 1988. Novel regulators of bone formation: Molecular clones and activities. Science 242:1528-1534.

Xiao G, Gopalakrishnan R, Jiang D, Reith E, Benson MD, Franceschi RT. 2002. Bone morphogenetic proteins, extracellular matrix, and mitogen-activated protein kinase signaling pathways are required for osteoblast-specific gene expression and differentiation in MC3T3-E1 cells. J Bone Miner Res 17:101-110. 
Yaffe D, Saxel O. 1977. Serial passaging and differentiation of myogenic cells isolated from dystrophic mouse muscle. Nature 270:725-727.

Yamashita H, ten Dijke P, Huylebroeck D, Sampath TK, Andries M, Smith JC, Heldin CH, Miyazono K. 1995. Osteogenic protein-1 binds to activin type II receptors and induces certain activin-like effects. J Cell Biol 130: 217-226.

Yang S, Wei D, Wang D, Phimphilai M, Krebsbach PH, Franceschi RT. 2003. In vitro and in vivo synergistic interactions between the Runx2/Cbfa1 transcription factor and bone morphogenetic protein-2 in stimulat- ing osteoblast differentiation. J Bone Miner Res 18:705715 .

Zhou S, Glowacki J, Yates KE. 2004. Comparison of TGFbeta/BMP pathways signaled by demineralized bone powder and BMP-2 in human dermal fibroblasts. J Bone Miner Res 19:1732-1741.

Zhu W, Rawlins BA, Boachie-Adjei O, Myers ER, Arimizu J, Choi E, Lieberman JR, Crystal RG, Hidaka C. 2004. Combined bone morphogenetic protein-2 and -7 gene transfer enhances osteoblastic differentiation and spine fusion in a rodent model. J Bone Miner Res 19:20212032. 